\title{
Titi Kala Mangsa by Sujiwo Tejo: Representation of Time and The Cosmic World in Javanese Culture
}

\author{
A Rahmawati ${ }^{1}$ and T I Setyani ${ }^{2}$ \\ ${ }^{1}$ Regional Literature Study Program for Javanese Literature, Faculty of Cultural Sciences, \\ University of Indonesia, Depok 16424, West Java, Indonesia. \\ ${ }^{2}$ Departement of Literature, Faculty of Humanity, Universitas Indonesia, Depok 16424, West Java, \\ Indonesia. \\ E-mail: turita.indah@gmail.com
}

\begin{abstract}
In the lyrics of the song Titi Kala Mangsa (TKM) there is an implied message that is not easily read by the lay audience. This study aims to describe the meaning of time and messages from TKM lyrics. The discussion uses interpretive theory to uncover meaning through the structure of the TKM lyrics which refers to the theory of the continuity of Riffaterre's expression, that is the reading of meaning with heuristic and hermeneutic interpretations. Based on the description of the meaning, the message that contained in the TKM song can be known. The results of the analysis represent that the time in the TKM song lyrics has meaning related to the cosmos, namely the microcosm (human) and the macrocosm (universe). Humans have wasted their time when they have to carry out their roles; maintain balance of himself. Human imbalance makes the universe chaos. The message revealed is; humans can carry out roles according to their time. If it is maintained, it will not happens caused by anger (ora nrima ing pandum) on the influence of Batara Kala. By being wary of times, the misery will be ends and human life becomes balanced.
\end{abstract}

Keywords: Titi Kala Mangsa; Kala 'Time', Kosmos; Heuristik, Hermeneutik

\section{INTRODUCTION}

Literature is a forum for communication of personal experience and imagination of the author. The container can be in the form of drama scripts, novels, short stories, and poems. The experience that given to the reader is a great awareness and understanding of the world [1]. Literary opus also 
serve as a reflection of the social conditions. From this reflection, humans and their problems are described in literary opus as a reflection of life. Existing social problems become ideas to create and convey criticism, so that these thoughts can be used as evaluations.

One forum for the author to communicate his criticism is through poetry. Poetry is a place for authors to express their thoughts imaginatively. The literary function in poetry provides an opportunity for imaginative authors to participate in it[1]. Thus, poetry can enrich the mind and experience, which makes the reader more able to feel what is owned in his life.

The song lyrics included in literary opus that has a solid form and meaningful poetry. Lyric poetry usually expresses deep feelings. So naturally most poems of this type relate to the topics of love, reflection, religion, death, philosophy and others which are related to the deepest appreciation of the poet's soul [2]. As with other literary opus, song lyrics are the result of the experience of a song writer and can express the reality of life and being a tool in social criticism [3]. One of the song lyrics that gives the author a sense of appreciation is Sujiwo Tejo's TKM.

Sujiwo Tejo is a musician who often creates songs related to social. During the reign of the orde baru, Sujiwo Tejo created a song called Titi Kala Mangsa (TKM). The song TKM is well known by Indonesian people because it touches the hearts of its listeners. Unfortunately not all listeners can understand the message that conveyed by Sujiwo Tejo in the lyrics of the song TKM cause of the language that used in the lyrics of the song TKM is an archaic and poetic Javanese language. Further interpretation is needed, so that the general public can understands the messages that conveyed by Sujiwo Tejo. Therefore, the purpose of this study is to describe the structure, meaning, and messages.

This research refers to the study "Analisis Lagu No Woman No Cry oleh Bob Marley Melalui Pendekatan Sosiologi Sastra". The study discusses about No Woman No Cry song which focuses on biographical and socio-historical background knowledge. The research was preceded by a method of interpretation through the stages of the heuristic and hermeneutics. With heuristic reading, the research changes the song lyrics into paraphrase and interpreted into Indonesian, so that it gets a literal understanding of meaning to find explicit meaning (actual meaning).

The next step is the hermeneutic stage which is a decomposition process that moves from the contents and explicit meaning to the implicit meaning. The message of the text is then associated with other elements from outside the text, such as the socio-historical setting, culture, and biography of the author. The research was also supported by the theories of Hypolite Taine about race, moment, and millieu which explained that a literary text is a portrait of reality in a particular society (race) in certain times and circumstances (moment a nd millieu) [4].

From the heuristic and hermeneutic stages, the understanding of the No Woman No Cry song lyrics became easier. By using the heuristic and hermeneutic stage, this study refers to "Analisis Lagu No Woman No Cry oleh Bob Marley Melalui Pendekatan Sosiologi Sastra". However, this study examines the song TKM and focuses more on meaning based on Riffaterre's theory of Semiotic of Poetry, which also uses the stages of heuristic and hermeneutic reading to achieve its interpretation. 


\title{
2. METHOD
}

This research use an interpretive analysis step. Data sources are obtained through listening techniques and then recording TKM song lyrics, then analyzing their meaning through heuristic and hermeneutic readings and structures. Structural analysis is carried out with the theory of the continuity of expression by Riffaterre, while the analysis of meaning is done at the stage of interpretation. Interpretation is done through heuristic and hermeneutic readings. The heuristic stage is the reading of the first stage which produces a literal understanding of meaning to find the explicit meaning. This can be done by paraphrasing the song lyrics or perfecting the language more clearly before the second reading is done to be studied and interpreted hermeneutically.

\section{DISCUSSION}

Analysis of meaning, and understanding of the concept of time and the cosmos in the lyrics of TKM begins with the recording of the lyrics of the song TKM through listening techniques. The technique of recording is done by recording using standard Javanese language. The song TKM that was listened to was sourced from the Sujiwo Tejo's YouTube channel. Furthermore, song lyrics are recorded and analyzed in terms of structure, meaning and message.

\subsection{Meanings}

To get the express or implied meaning, the interpretation of the lyrics of the song TKM is used through the stages of heuristic and hermeneutic reading. The following is a description of heuristic and hermeutic readings on the lyrics of the song TKM :

\author{
Structure \\ $T K M$ song lyrics \\ Wong takon wosing dur angkara \\ Antarane rika aku iki \\ Sumebar ron-ronaning kara \\ Janji sabar, sabar \\ Sak watara wektu \\ Kala mangsane \\ Titi kala mangsa \\ Pamujiku dibisa \\ Sinuda kurban jiwangga \\ Pamungkase kang dur angkara \\ Titi kala mangsa . \\ (Sujiwo Tejo)
}

The lyrics of the song TKM use the style of poetic language, which is the language commonly used in poetry. This kind of language usually containing metaphors and unsustainable expressions. Riffaterre [5] explains that the continuity of expressions in a poem can be caused by three things, 
namely displacing of meaning, distorting of meaning, and creating of meaning. The displacing of meaning means, the displacing of a meaning of a word or sentence that is replaced by another meaning through figurative language. In replacing this meaning, a word meaning has another meaning (not according to the real meaning). The displacing of meaning is usually through figurative language in the form of simile, metaphor, metonimie, personification, and others. In the lyrics "sumebar ron-ronaning kara" there are displacing meaning through metaphor. The presence of leaves in the third stanza becomes a question, because it is not in one context with the previous stanza. It is a metaphor that describes a chaotic situation and there are many problems in the cosmic world. The number of problems is described as leaves kara scattered disheveledly.

Distorting of the meaning of poetic language deviates from the meaning of written language (language that used in text). The distortion of meaning is caused by three things, ambiguity, contradiction, and non-sense [5]. Creating of meaning is the creation of new meanings caused by the visual form of poetry. The visual form of the poem linguistically has no meaning, but when viewed in terms of semiotics, the elements are a sign that can create new meaning in poetry. According to Riffaterre the creation of a new meaning occurs because it is caused by the existence of a visual form of poetry which includes, rima, enjambemen and typography [5].

Rhyme is a pattern that found in poetry. Rhyme is divided into two, namely external rhyme and internal rhyme. External rhyme is the interlocation of sound on poetry lines, while internal rhyme is the sound of sound in a poetry array [6]. Based on the explanation above, it can be seen that the lyrics of TKM have external rhymes. Although each stanza does not have the same verses of a-b-a-b, but the lyrics of the song still have the aesthetic form of poetry in the story. In the lyrics of TKM , it appears that even though the writer is in a sad feeling, he still pays attention by his aesthetics forms.

Enjambment is the decapitation of words into the next line. This beheading in grammar has no meaning, but in the literary convention it serves as an emphasis or affirmation on the line. In the lyrics of TKM enjambment, it is found in the sentence "Janji sabar, sabar sak watara wektu". Enjambment here is used as a confirmation to be patient.

\section{a. Heuristic Reading}

The reading of the heuristic is the reading of the first stage which produces an understanding of the meaning literally to find the express meaning (actual meaning). This can be done by paraphrasing or completing the lines of song lyrics into whole sentences and perfecting the language more clearly before the second reading is done to be examined and interpreted hermeneutically.

\section{Stanza 1}

Wong takon wosing dur angkara. Antarane rika aku iki sumebar ron-ronaning kara. Meaning: Humans ask when will the anger be ended? Among you and me, there are the leaves of kara that scattered disheveledly.

Stanza 2

Janji sabar, sabar sak watara wektu. Kala mangsane, titi kala mangsa. Meaning: Be patient! wait for a while. Someday, once upon a time.

Stanza 3

Pamujiku dibisa sinuda kurban jiwangga. Pamungkase kang dur angkara, Titi kala mangsa. 
Meaning: My prayer was granted, the loss of physical body loss. The end of this anger is time.

\section{b. Hermeneutic Reading}

Hermeneutics is a decomposition process that moves from the contents and express meaning to the meaning that is implied or hidden. In the first stanza, there is the concept of the cosmos 'world'. The physical part of the human self and all its desires is a representation of the little universe 'microcosm' and the universe 'macrocosm' is a representation of things outside the human self [7]. In the lyrics of TKM, the jagad cilik is represented by humans, while the jagad gedhe is represented by the universe. Javanese culture prioritizes relationships that are in harmony between the microcosm and the macrocosm. If the balance between microcosm and macrocosm is disturbed, chaos will occur. However, humans believe there is a power beyond their ability (macrocosm) that can be asked for help or resolve the anger that happens. This is a representation of the relationship between the microcosm and the macrocosm. In this stanza, it is described that the cosmos (macrocosm) occupied by humans (microcosm) is in chaos, because humans do not maintain a balance between themselves and the macrocosm that has an effect on the universe.

In the second verse, there was a concept of time in the TKM song. In Javanese culture, the concept of time is very important, because human life is always depended of time. At this time it warns humans to make the best use of time. People who do not make good use of time will be ignorant and will fall prey to Batara Kala [8]. Batara Kala is a symbol of human lust. Lust should be maintained so that humans are not consumed by time. This can be overcome by the process of Ruwatan Sukerta. Sukerta is a disease or disgrace concerning several human groups, for example kendhana-kendhini, ontang-anting, uger-uger lawang, sendhang kapit pancuran, anak bungkus, etc. Described in the TKM lyrics that humans lose because they don't use their time well. He did not carry out his role in maintaining a balance between the microcosm and the macrocosm.

\subsection{Messages}

Referring to the meaning above, there is a message that humans can carry out (nglakoni) their roles according to the right time. If it is maintained, it will not experience suffering caused by anger (ora nrima ing pandum) for the influence of Batara Kala.

By being wary of times, misery will be over. The absence of misery, the life of a human being becomes balanced (harmony). Thus, humans must always maintain their balance (microcosm), so that the universe (macrocosm) is always in a balanced state. Because if the microcosm has been balanced, then the macrocosm will indirectly be balanced.

\section{CONCLUSIONS}

TKM songs have a poetic language structure, namely the language used in poetry and usually there are metaphors and unsustainable expressions. The continuity of the expression is contained in the sentence "Sumebar ron-ronaning kara". There is a substitution of meaning through a metaphor that describes a chaotic situation and there are many problems. The number of problems is reported 
as leaves of kara which are scattered in disarray. There is also the creation of meaning through enjambement in the sentence "Janji sabar, sabar sak watara wektu". Enjambemen here is used as a confirmation so that people are patient.

Through hermeneutic reading, there is a representation of kala 'time' and jagad 'cosmos' in Javanese culture. The representation of the universe of cosmos is stated in the first stanza. Described that the cosmos that occupied by humans is chaotic because the microcosm does not maintain balance with the macrocosm. The representation is in the second stanza. Described that humans as microcosms do not make good use of time, causing chaos to the macrocosm.

\section{REFERENCES}

[1] G. Rizanur, Pengajaran Sastra Indonesia Respons dan Analisis. Padang: Dian Dinamika Press, 1998.

[2] Siswantoro, Metode Penelitian Sastra. Surakarta: Pustaka Pelajar, 2010.

[3] A. Tri Laksana, "Musik Pengamen Jalanan (Studi Tentang Fungsi Musik Jalanan Sebagai Media Pendidikan Moral Dan Kritik Sosial)," Agastya J. Sej. dan Pembelajarannya, vol. 4, no. 1, p. 27, Jan. 2014.

[4] I. Y. P. Awom, "Analisis Lagu No Woman No Cry oleh Bob Marley melalui Pendekatan Sosiologi Sastra," Melanes. J. Ilm. Kaji. Bhs. dan Sastra, vol. 2, no. 1, p. 51, Apr. 2018.

[5] R. D. Pradopo, Beberapa Teori Satra, Metode Kritik, Dan Penerapannya. Yogyakarta: Pustaka Pelajar, 2011.

[6] M. Riffaterre, Semiotic of Poetry. indiana: Univ Press, 1978.

[7] Surastina, Pengantar Teori Sastra. Yogyakarta: Elmatera, 2018.

[8] D. Darmoko, "Ruwatan: Upacara Pembebasan Malapetaka Tinjauan Sosiokultural Masyarakat Jawa," Makara Hum. Behav. Stud. Asia, vol. 6, no. 1, p. 30, Jun. 2002. 